\title{
Aplikasi Persamaan Diferensial Dalam Mengestimasi Jumlah Penduduk dengan Menggunakan Model Eksponensial dan Logistik
}

\author{
Nasrun Rozikin ${ }^{* *}$, Ketut Sarjana ${ }^{2}$, Arjudin $^{2}$, Nurul Hikmah $^{2}$ \\ ${ }^{1}$ Mahasiswa Pendidikan Matematika, Universitas Mataram, Mataram, Indonesia \\ 2 Pendidikan Matematika, Universitas Mataram, Mataram, Indonesia
}

*Corresponding Author e-mail: nasrunrozikin26@gmail.com

Received: 29-01-2021; Revised: 25-03-2021; Published: 25-03-2021

\begin{abstract}
This research was aimed to describe the application of differential equations of the population growth model in the City of Mataram, which is an exponential and logistic models for estimating the population of the City of Mataram in 2024. The research method used in this research is descriptive research with a qualitative approach carried out by observation and analyze the subject. The subject of this research was data on the population of the City of Mataram from 2006 to 2019. Meanwhile, to determine the accuracy and validity of the research data, the triangulation of sources was used. The data used comes from the Dispendukcapil and BPS the City of Mataram. The research result, it shows that the exponential model has an accuracy rate of $99,6 \%$, which is very accurate, while for estimating with a logistic model each criterion is very accurate but the confidence level is $97,9 \%$. Estimation results also show that population growth in the city of Mataram in the future will slowdown in its growth every 2 years, with an average decrease of $0.5 \%$.
\end{abstract}

Keywords: differential equation, exponential model, logistic model

\begin{abstract}
Abstrak
Penelitian ini bertujuan untuk mendeskripsikan aplikasi persamaan diferensial pada model pertumbuhan penduduk Kota Mataram yaitu model eksponensial dan model logistik dan menentukan besarnya pendugaan jumlah penduduk Kota Mataram pada tahun 2024. Metode Penelitian yang digunakan dalam penelitian ini adalah penelitian deskriptif dengan pendekatan kualitatif yang dilakukan dengan cara observasi dan menganalisa subjek. Data dalam penelitian ini adalah data jumlah penduduk Kota Mataram tahun 2006 hingga 2019. Sedangkan untuk mengetahui keakuratan dan keabsahan data penelitian digunakan triangulasi sumber. Untuk data yang digunakan berasal dari Dinas Kependudukan dan Catatan Sipil (Dispendukcapil) dan Badan Pusat Statistik (BPS) Kota Mataram. Hasil penelitian, menunjukkan bahwa model pertumbuhan eksponensial memiliki tingkat keakuratan sebesar 99,6\% yakni sangat akurat, sedangkan untuk pengestimasian dengan model pertumbuhan logistik masing-masing berkriteria sangat akurat juga tetapi tingkat kepercayaannya sebesar 97,9\%. Hasil estimasi juga menunjukkan bahwa pertumbuhan penduduk di Kota Mataram pada masa yang akan datang mengalami perlambatan dalam pertumbuhannya setiap 2 tahun sekali yakni dengan rata-rata penurunan sebesar $0,5 \%$.
\end{abstract}

Kata Kunci: persamaan diferensial, model eksponensial, model logsitik

Cara Mengutip

Rozikin, N., Sarjana, K., Azmi, S., \& Hikmah, N. (2021). Aplikasi Persamaan Diferensial Dalam Mengestimasi Jumlah Penduduk dengan Menggunakan Model Eksponensial dan Logistik. Griya Journal of Mathematics Education and Application, 1(1), 11-18. 


\section{PENDAHULUAN}

Tidak ada sesuatu yang tidak mengalami perubahan kecuali perubahan itu sendiri. Hal ini tidak terkecuali terhadap kedudukan suatu populasi untuk mengalami perubahan (pertumbuhan). Pertumbuhan populasi pada suatu wilayah tertentu merupakan hal penting karena dapat mempengaruhi kemajuan dan kesejahteraan wilayah tersebut. Akan tetapi, jika pertumbuhan ini dibiarkan, maka dalam kurun waktu tertentu bukan tidak mungkin akan terjadi suatu ledakan populasi sehingga rentan menimbulkan masalah-masalah kependudukan, seperti tingkat pengangguran yang tinggi, kemiskinan, kelaparan, dan dampak negatif lainnya (Nurkholipah, Anggriani, \& Supriatna, 2017).

Berdasarkan sumber data dari Badan Pusat Statistik (BPS) Nusa Tenggara Barat (2019)bahwa besarnya populasi Kota Mataram mencapai rata-rata laju pertumbuhan sebesar $2,7 \%$ pertahunnya dengan luas wilayah hanya sebesar $61,30 \mathrm{~km}^{2}$ saja. Jika dilihat luas wilayah dan populasi yang tumbuh, maka dapat dikatakan bahwa luas wilayahnya tidak sebanding dengan jumlah populasinya saat ini dengan asumsi bahwa apabila populasi tumbuh menjadi dewasa dan teratasi dengan baik, serta jumlah yang besar membutuhkan tempat tinggal sehingga tidak mungkin hal ini dapat terpenuhi. Saat ini yang pertumbuhan Kota Mataram dalam jangka waktu yang tidak diketahui akan terus tumbuh dari waktu ke waktu (kontinu) dan kemungkinan dalam waktu dekat akan semakin membesar jika lajunya tidak ditekan.

Dalam matematika, penambahan populasi di Kota Mataram ini dikenal dengan istilah diferensial. Diferensial difenisikan sebagai pertambahan dari suatu fungsi $y=f(x)$ pada sebarang variable bebas $x$ dan pertambahan dari variable bebas $x$ disebut $d x$ (Purcell \& Varberg, 1993). Diferensial merupakan cabang ilmu matematika, yang permodelannya dapat merefresentasi suatu fenomena yang ada di lingkungan kehidupan sehari-hari (Putri, 2015). Sejalan dengan fenomena yang terjadi, bahwa banyaknya individu dalam suatu populasi (P) akan bertambah seiring berjalannya waktu (t), dan laju pertumbuhan populasi merupakan suatu diferensial (Stewart, 2003).

Pada tahun 1798, Thomas Malthus menyatakan bahwa pertumbuhan populasi akan tumbuh secara eksponensial, artinya populasi akan terus bertumbuh secara kontinu dan tidak dibatasi oleh lingkungan sehingga tidak terjadi suatu kompetisi untuk mendapatkan sumberdaya (Nurkholipah et al., 2017). Sejalan dengan pernyataan tersebut, pertumbuhan kota Mataram dapat dikatakan sebagai pertumbuhan eksponensial karena berdasarkan data dari BPS, pertumbuhannya selalu mengalami penambahan.

Selanjutnya teori lain datang dari Pierre Verhulst (dalam Nurkholipah et al., 2017) yang menyatakan bahwa pertumbuhan populasi tidak hanya bergantung pada jumlahnya (yang akan terus tumbuh) tetapi juga sejauh mana batas dari sumberdaya/logistik yang tersedia untuk mendukung kehidupan di dalamnya. Didasarkan pada teori Verhulst, Kota Mataram juga merupakan pertumbuhan yang 
kontinu akan tetapi sumberdaya yang ada juga akan menjadi pembatas untuk populasi tumbuh karena setiap individu dalam populasi membutuhkan sedikit dari sumberdaya.

Berdasarkan penjelasan di atas, maka akan dilakukan suatu proyeksi dengan model tersebut terhadap pertumbuhan penduduk Kota Mataram di masa yang akan datang dengan beracuan pada data jumlah penduduk yang telah diketahui, yang tujuannya adalah untuk mengetahui bagaimana dinamika pertumbuhan dan besarnya populasi Kota Mataram di pada tahun 2024.

\section{METODE}

Jenis penelitian yang digunakan adalah deskriptif dengan pendekatan kualitatif. Tujuannya adalah untuk mendeskripsikan kejadian dalam suatu peristiwa, baik itu untuk deskripsi makna di balik data, interaksi antar variabel, pengembangan teori dan variabel-variabel lainnya (Sugiyono, 2010). Penelitian ini dilakukan di Badan Pusat Statistik Kota Mataram pada saat semester genap tahun ajaran 2019/2020. Dalam penelitian ini yang menjadi subjek penelitian adalah jumlah penduduk Kota Mataram pada tahun 2024, sedangkan obyeknya adalah persamaan diferensial model eksponensial dan logistik.

Pengumpulan data dilakukan dengan studi kepustakaan dan teknik keabsahan data menggunakan triangulasi sumber. Data dalam penelitian ini adalah data jumlah penduduk dari tahun 2006 hingga 2019, yang bersumber dari Dinas Kependudukan dan Catatan Sipil (DUKCAPIL) dan Badan Pusat Statistik (BPS) Kota Mataram. Selain itu, menilai kecocokan dari suatu model dalam proyeksi penduduk digunakan Mean Absolute Percentage Error (MAPE). Konsep dari MAPE sangat penting digunakan dalam memilih model terbaik dari model-model lainnya. Sebuah model dengan MAPE yang lebih kecil adalah model yang dipilih dari model lainnya.

Bentuk matematika dari MAPE ini adalah sebagai berikut:

$$
M A P E=\frac{1}{N} \sum_{t=1}^{N}\left|\frac{P_{(t)}-\bar{P}_{(t)}}{P_{(t)}}\right| \times 100 \%
$$

dimana $P_{(t)}$ adalah besarnya populasi sebenarnya pada waktu $t, \bar{P}_{(t)}$ adalah besarnya proyeksi populasi pada waktu $t$, dan $N$ adalah jumlah observasi data dari populasi [1]. Untuk interpretasi nilai MAPE disajikan sebagai berikut:

Tabel 1. Interpretasi Mean Absolute Percentage Error

\begin{tabular}{cc}
\hline Nilai MAPE & Interpretasi MAPE \\
\hline MAPE $<10 \%$ & Sangat akurat \\
$10 \% \leq$ MAPE $<15 \%$ & Sangat baik \\
$15 \% \leq$ MAPE $<20 \%$ & Baik \\
$20 \% \leq$ MAPE $<50 \%$ & Masuk akal \\
MAPE $>50 \%$ & Tidak akurat \\
\hline
\end{tabular}




\section{HASIL DAN PEMBAHASAN}

Data pertumbuhan penduduk Kota Mataram yang digunakan dalam proyeksi penduduk pada tahun 2024 menggunakan model Eksponensial dan Logistik adalah data pertumbuhan penduduk tahun 2006 sampai dengan tahun 2019. Berikut ditunjukkan oleh tabel 2

Tabel 2. Data pertumbuhan penduduk di Kota Mataram tahun 2006-2019.

\begin{tabular}{cccc}
\hline Tahun (t) & $\begin{array}{c}\text { Jumlah Penduduk } \\
\text { (jiwa) }\end{array}$ & Tahun (t) & $\begin{array}{c}\text { Jumlah Penduduk } \\
\text { (jiwa) }\end{array}$ \\
\hline 2006 & 353.183 & 2013 & 419.641 \\
2007 & 356.141 & 2014 & 441.064 \\
2008 & 362.243 & 2015 & 450.226 \\
2009 & 375.506 & 2016 & 459.314 \\
2010 & 402.843 & 2017 & 468.509 \\
2011 & 406.910 & 2018 & 477.476 \\
2012 & 413.210 & 2019 & 486.715 \\
\hline \multicolumn{4}{c}{ Sumber: Badan Pusat Statistik Nusa Tenggara Barat }
\end{tabular}

\subsection{Analisis model eksponensial pertumbuhan populasi Kota Mataram}

Dalam merumuskan permodelan pertumbuhan populasi dibutuhkan hukum yang mempengaruhi populasi dan fakta eksperimental yakni:

1) Hukum Kekekalan Populasi

Perubahan dari suatu populasi dalam periode tertentu dapat mengalami pertambahan yang disebabkan oleh banyaknya individu yang masuk (kelahiran dan imigrasi), dan dapat pula mengalami pengurangan yang disebabkan oleh banyaknya individu yang keluar (kematian dan emigrasi).

2) Fakta Eksperimental Populasi

Individu di dalam suatu populasi yang bereproduksi dan yang mati pada suatu periode waktu tertentu adalah konstan.

Selanjutnya, didasarkan pada (Toaha, 2008) dan beberapa hal di atas, serta fenomena Kota Mataram, berikut ini asumsi-asumsi yang digunakan dalam pertumbuhan eksponensial:

a) Laju kelahiran dan kematian adalah konstan dan kontinu;

b) Tidak ada struktur gender;

c) Tidak ada perbedaan usia;

d) Tidak ada waktu tunda (time delay); dan,

e) Migrasi diabaikan.

Misalnya $\mathrm{P}$ menunjukkan besarnya populasi dan $\mathrm{t}$ menunjukkan waktu maka $\mathrm{P}_{(\mathrm{t})}$ merupakan besarnya populasi pada satuan waktu t. Sedangkan besarnya populasi pada satuan waktu berikutnya dinotasikan dengan $\mathrm{P}_{(\mathrm{t}+1)}$. Berdasarkan asumsi diperoleh model matematis: 


$$
\begin{aligned}
& P_{(t+1)}=P_{(t)}+B-A \\
& \frac{\Delta P}{\Delta t}=B-A
\end{aligned}
$$

dengan :

$P_{(t+1)}=$ perubahan populasi dari satu waktu ke waktu berikutnya

$\frac{\Delta P}{\Delta t}=$ besarnya perubahan populasi dari waktu $t$ ke $t+1$

$B=$ angka kelahiran

$A=$ angka kematian

Oleh karena besarnya perubahan dari suatu populasi dari waktu ke waktu berikutnya merupakan suatu diferensial (Stewart, 2003), sedemikian sehingga persamaan (2) menjadi

$$
\frac{d P}{d t}=B-A
$$

Stewart lebih lanjut menyatakan bahwa perubahan yang terjadi dalam suatu populasi itu bergantung pada besarnya laju pertumbuhan populasi tersebut. Kemudian dengan asumsi tersebut dipandang pula bahwa besarnya angka kelahiran akan bergantung pada laju kelahiran $(\beta)$ dan besarnya angka kematian akan bergantung pula pada laju kematian $(\alpha)$, yaitu:

$$
\begin{aligned}
& B=\beta P_{(t)} ; \beta=\text { konstanta pembanding angka kelahiran } \\
& A=\alpha P_{(t)} ; \alpha=\text { konstanta pembanding angka kematian }
\end{aligned}
$$

Sehingga persamaan (3) menjadi

$$
\frac{d P}{d t}=\beta P_{(t)}-\alpha P_{(t)}
$$

Jika $\beta-\alpha=r$, dengan $r$ dinyatakan sebagai laju pertumbuhan dari populasi, maka diperoleh

$$
\frac{d P}{d t}=r P_{(t)} \quad ; P_{(t)}>0
$$

dimana $\mathrm{r}$ adalah suatu konstanta. Persamaan (5) merupakan persamaan diferensial linear orde satu. Penyelesaian untuk persamaan (5) dilakukan dengan cara pemisahan variabel sehingga diperoleh:

$$
P(t)=e^{r t+C}
$$

jika $\mathrm{e}^{\mathrm{c}}=\mathrm{A}$, maka

$$
P(t)=A e^{r t}
$$

untuk melihat konstanta A diamati bahwa apabila diberikan nilai awal $t=0$, sehingga besarnya populasi saat $t=0$ merupakan populasi awal $\left(\mathrm{P}_{0}\right)$, diperoleh

$$
P(0)=A e^{r .0}=A
$$


Jadi, A merupakan besarnya populasi awal $\left(\mathrm{P}_{0}\right)$. Sehingga, penyelesaian khusus dari persamaan (5) adalah

$$
P(t)=P_{0} e^{r t}
$$

dimana: $P(t)=$ besarnya individu dalam populasi pada waktu $t$.

$P_{0}=$ besarnya populasi saat $t=0$.

$r=$ laju pertumbuhan populasi dalam periode waktu tertentu.

$t=$ waktu.

Persamaan (7) disebut sebagai Model Pertumbuhan Eksponensial. Untuk menentukan harga daripada $r$ atau laju dari pertumbuhan populasi dapat diturunkan dari persamaan (7), yaitu

$$
r=\frac{\ln \left(\frac{P(t)}{P_{0}}\right)}{t}
$$

\subsection{Aproksimasi dan proyeksi model eksponensial}

Untuk mengetahui valid atau tidaknya model ini, peneliti melakukan beberapa aproksimasi tergantung dari selang waktu pengambilan data sampelnya, yakni selang 1 hingga 5 tahun. Oleh karena model hanya dapat memproyeksi untuk periode waktu yang singkat saja, sehingga untuk menguji validitasnya peneliti menggunakan data jumlah penduduk Kota Mataram tahun 2014 hingga 2019. Untuk setiap harga (r) yang disubstitusikan ke persamaan eksponensial akan membentuk beberapa permodelan. Kemudian diperoleh laju pertumbuhan dan Mean Absolute Persentage Error (MAPE) masing-masing selang pengambilan sampel yakni sebagai berikut:

Tabel 3. Laju Pertumbuhan dan MAPE Masing-Masing Selang Pengambilan Sampel Model Eksponensial

\begin{tabular}{cccc}
\hline Aproksimasi & Populasi awal $\left(\boldsymbol{P}_{\mathbf{0}}\right)$ & Laju pertumbuhan $(\mathrm{r})$ & MAPE (\%) \\
\hline \multirow{2}{*}{ I } & 2014 & 0,02056 & 2,28 \\
& 2015 & 0,01998 & 1,12 \\
& 2016 & 0,01982 & 1,19 \\
& 2017 & 0,01895 & - \\
II & 2014 & 0,02027 & 1,34 \\
& 2015 & 0,01990 & 0,51 \\
& 2016 & 0,01939 & 0,33 \\
III & 2017 & 0,01906 & 0,05 \\
& 2014 & 0,02012 & 1,01 \\
IV & 2015 & 0,01958 & 0,48 \\
& 2016 & 0,01931 & 0,33 \\
V & 2014 & 0,01983 & 0,79 \\
& 2015 & 0,01948 & 0,55 \\
& 2014 & 0,02019 & 1,17 \\
& 2015 & 0,01982 & 0,79 \\
& 2016 & 0,01961 & 0,76 \\
\hline
\end{tabular}

Tabel 3. menunjukkan bahwa hasil aproksimasi dengan interval waktu 2 dan 3 tahun dengan populasi awal tahun 2016 memiliki MAPE terkecil (0,33\%) dengan kriteria sangat akurat. Kemudian dipandang kecendrungan error dari aproksimasi tersebut 
sehingga peneliti lebih memilih permodelan dengan interval 2 tahun dengan populasi awal tahun 2016 yang dinyatakan sebagai model yang valid untuk digunakan dalam memproyeksi jumlah penduduk Kota Mataram pada tahun 2024. Adapun permodelan tersebut sebagai berikut adalah

$$
P(t)=P_{0} e^{(0,01939) t}
$$

Selanjutnya untuk memproyeksi penduduk Kota Mataram pada tahun 2024, diperoleh $\mathrm{t}=8$. Adapun hasil estimasi jumlah penduduk Kota Mataram Pada Tahun 2024 menggunakan model pertumbuhan eksponensial adalah sekitar 526.085 jiwa.

\subsection{Analisis model logistik pertumbuhan populasi Kota Mataram}

Pada tahun 1838 Pierre Verhulst melakukan pengembangan dari model eksponensial (Zulkarnaern, 2014). Hal ini dikarenakan suatu populasi seringkali meningkat secara eksponensial pada awalnya tetapi melambat ketika populasi mendekati kapasitas tampung karena sumberdaya yang terbatas (Stewart, 2003). Oleh karena setiap populasi tumbuh dan tumbuh, sehingga jumlahnya semakin membesar yang kemudian masing-masing individu akan berkompetisi hanya mendapatkan sebagian kecil dari sumberdaya yang semakin lama semakin habis. Berikut asumsi yang digunakan dalam pertumbuhan populasi yang dibatasi oleh logistik:

a) Laju kelahiran $(\beta)$ adalah konstan;

b) Laju kematian $(\alpha)$ tidaklah konstan (linear);

c) Model ini merupakan pengembangan dari model eksponensial, asumsi-asumsi lainnya adalah sama yakni tidak ada struktur gender, tidak ada perbedaan umur, migrasi diabaikan, dan tidak adanya waktu tunda (Toaha, 2008).

Berdasarkan asumsi-asumsi di atas, dapat dikembangkan permodelan pada model eksponensial yakni sebagai berikut:

$$
\frac{d P}{d t}=\beta P_{(t)}-\alpha P_{(t)}-\gamma P_{(t)}^{2} \quad ; \quad \gamma>0
$$

dimana $\gamma$ merupakan konstanta pembanding dari angka kematian karena kepadatan. Oleh karena $(\beta-\alpha)=r$, sehingga:

$$
\frac{d P}{d t}=r P_{(t)}-\gamma P_{(t)}^{2}
$$

Oleh karena kepadatan pada suatu wilayah disebabkan oleh laju pertumbuhan ( $r$ ) yang tinggi kemudian mengakibatkan terjadinya penyusutan terhadap sumberdaya/daya tampung $(K)$ sehingga peningkatan pada angka kematian dalam populasi akan terjadi. Kemudian dari hal tersebut, persamaan (10) menjadi:

$$
\frac{d P}{d t}=r P_{(t)}\left(1-\frac{P_{(t)}}{K}\right)
$$


Perhatikan bahwa dari persamaan (11) dapat diketahui, jika populasi masih dapat didukung oleh wilayah $\left(P_{(t)}<K\right)$, maka $\frac{P_{(t)}}{K}$ mendekati 0 dan besarnya pertumbuhan populasi akan sebanding dengan besarnya populasi saat itu $\left(\frac{d P}{d t} \approx r P_{(t)}\right)$. Namun jika populasi mendekati daya tampungnya $\left(P_{(t)} \rightarrow K\right)$, maka $\frac{P_{(t)}}{K} \rightarrow 1$, sehingga $\frac{d P}{d t} \rightarrow 0$, yang berarti bahwa penambahan (atau penurunan) populasi melambat. Jika populasi masih mungkin untuk bertambah dikarenakan kapasitas tampung masih mendukung $\left(0<P_{(t)}<K\right)$, maka pertumbuhannya akan mengalami penambahan $\left(\frac{d P}{d t}>0\right)$. Akan tetapi jika populasi melampaui kapasitas tampungnya $\left(P_{(t)}>K\right)$, maka $1-\frac{P_{(t)}}{K}$ bernilai negatif, sehingga besarnya perubahan populasi akan mengalami penurunan $\left(\frac{d P}{d t}<0\right)$.

Penyelesaian dari persamaan logistik dicari dengan pemisahan variabel, diperoleh:

$$
\begin{aligned}
\int \frac{1}{P} d P+\int \frac{1}{K-P} d P & =\int r d t \\
\ln |P|-\ln |K-P| & =r t+C \\
\ln \left(\frac{P}{K-P}\right) & =r t+C \\
P(t) & =\frac{K e^{r t+C}}{1+e^{r t+C}}
\end{aligned}
$$

Jika persamaan (12) diberikan nilai awal $t=0$ dan $P(0)=P_{0}$, maka diperoleh:

$$
C=\ln \left(\frac{P_{0}}{K-P_{0}}\right)
$$

Selanjutnya nilai $C$ disubstitusi ke dalam persamaan (12),

$$
\begin{aligned}
P(t) & =\frac{K e^{r t+\ln \left(\frac{P_{0}}{K-P_{0}}\right)}}{1+e^{r t+\ln \left(\frac{P_{0}}{K-P_{0}}\right)}} \\
P(t) & =\frac{K}{\left(e^{r t} P_{0}\right)^{-1} \cdot\left[K-P_{0}+e^{r t} P_{0}\right]} \\
P(t) & =\frac{K}{e^{-r t}\left(\frac{K}{P_{0}}-1\right)+1}
\end{aligned}
$$

\section{dimana:}

$P_{(t)}=$ besarnya populasi pada saat waktu $t$.

$e=$ bilangan Euler $(e=2,71828182845905)$.

$r$ = laju pertumbuhan penduduk.

$K=$ daya tampung.

$t=$ waktu.

Oleh karena $\gamma=\frac{r}{K}$, persamaan (13) menjadi: 


$$
P(t)=\frac{\frac{r}{\gamma}}{e^{-r t}\left(\frac{\frac{r}{\gamma}}{P_{0}}-1\right)+1}
$$

parameter $r$ dan $K$ dapat diperkirakan dari jumlah populasi untuk tiga waktu yang berbeda tetapi dalam space waktu pengambilan data sama. Jika $P_{0}$ adalah populasi pada $t=0$, maka $P_{1}$ pada saat waktu $t=T$ dan $P_{2}$ pada saat waktu $t=2 T$ dimana $T$ adalah bilangan asli.

a) Untukt $=T$, diperoleh

$$
\frac{1}{P_{T}}-\frac{e^{-r T}}{P_{0}}=\frac{\gamma}{r}\left[1-e^{-r T}\right]
$$

b) Untuk $t=2 T$, digunakan cara yang sama pada a), diperoleh

$$
\frac{1}{P_{2 T}}-\frac{e^{-2 r T}}{P_{0}}=\frac{\gamma}{r}\left[1-e^{-2 r T}\right]
$$

kemudian lakukan pembagian persamaan (16) dan (15) untuk mengeliminasi $\frac{\gamma}{r}$ diperoleh:

$$
\begin{gathered}
\frac{\frac{\gamma}{r}\left[1-e^{-2 r T}\right]}{\frac{\gamma}{r}\left[1-e^{-r T}\right]} \quad=\frac{\frac{1}{\mathrm{P}_{2 T}}-\frac{e^{-2 r T}}{\mathrm{P}_{0}}}{\frac{1}{\mathrm{P}_{\mathrm{T}}}-\frac{\mathrm{e}^{-\mathrm{rT}}}{\mathrm{P}_{0}}} \\
1+\mathrm{e}^{-\mathrm{rT}} \quad=\frac{\frac{1}{\mathrm{P}_{2 \mathrm{~T}}}-\frac{\mathrm{e}^{-2 \mathrm{TT}}}{\mathrm{P}_{0}}}{\frac{1}{\mathrm{P}_{\mathrm{T}}}-\frac{\mathrm{e}^{-\mathrm{rT}}}{\mathrm{P}_{0}}} \\
\mathrm{e}^{-\mathrm{rT}}=\frac{\mathrm{P}_{0}\left(\mathrm{P}_{2 \mathrm{~T}}-\mathrm{P}_{\mathrm{T}}\right)}{\mathrm{P}_{2 \mathrm{~T}}\left(\mathrm{P}_{\mathrm{T}}-\mathrm{P}_{0}\right)}
\end{gathered}
$$

Jadi, untuk menghitung laju pertumbuhan populasinya digunakan perhitungan:

$$
r=-\frac{1}{T} \ln \left|\frac{P_{0}\left(P_{2 T}-P_{T}\right)}{P_{2 T}\left(P_{T}-P_{0}\right)}\right|
$$

disubstitusikan persamaan (17) ke (15) sehingga diperoleh perhitungan untuk kapasitas tampungnya sebagai berikut:

$$
K=\frac{P_{T}\left(P_{2 T} P_{T}-2 P_{2 T} P_{0}-P_{0} P_{T}\right)}{P_{T}^{2}-P_{2 T} P_{0}}
$$

\subsection{Aproksimasi dan proyeksi model logistik}

Oleh karena pada model logistik tidak membatasi data yang harus digunakan, sehingga data sampel dalam penelitian dengan model ini adalah data jumlah penduduk Kota Mataram tahun 2006 hingga 2018. Alasan lainnya adalah untuk mengetahui dinamika pertumbuhan penduduk Kota Mataram dimasa selanjutnya dan faktor-faktor lain yang mungkin muncul. Adapun perkiraan nilai dari parameter $\mathrm{K}$ dan $\mathrm{r}$ sebagai berikut: 


\subsubsection{Kapasitas Tampung (K)}

Perkiraan jumlah penduduk yang dapat didukung dan ditampung oleh Kota Mataram yakni sebesar 598.179 jiwa.

\subsubsection{Laju Pertumbuhan}

Perhitungan untuk mencari harga $\mathrm{r}$ didasarkan pada interval waktu pengambilan data dengan space yang berbeda. Selain itu, peneliti juga melakukan perhitungan nilai $r$ dengan data populasi awal yang berbeda-beda pula, tujuannya adalah untuk melihat karakteristik dari pertumbuhan penduduk Kota Mataram. Hasilnya disajikan pada tabel berikut:

Tabel 4. Hasil Perhitungan Laju Pertumbuhan Model Logistik

\begin{tabular}{|c|c|c|c|c|c|c|c|}
\hline \multirow{2}{*}{ No } & \multirow{2}{*}{$\begin{array}{l}\text { Populasi } \\
\text { Awal }\left(\boldsymbol{P}_{\mathbf{0}}\right)\end{array}$} & \multicolumn{6}{|c|}{ Laju Pertumbuhan dengan space (tahun) } \\
\hline & & 1 & 2 & 3 & 4 & 5 & 6 \\
\hline 1 & 2006 & $-0,699$ & 0,684 & $-0,122$ & 0,122 & 0,057 & 0,039 \\
\hline 2 & 2007 & $-0,723$ & $-0,175$ & 0,395 & 0,098 & 0,061 & \\
\hline 3 & 2008 & $-0,617$ & 0,748 & 0,155 & 0,085 & 0,053 & \\
\hline 4 & 2009 & 1,985 & 0,507 & 0,067 & 0,055 & & \\
\hline 5 & 2010 & $-0,412$ & $-0,449$ & $-0,243$ & 0,030 & & \\
\hline 6 & 2011 & 0,010 & $-0,388$ & 0,120 & & & \\
\hline 7 & 2012 & $-1,138$ & 0,264 & 0,150 & & & \\
\hline 8 & 2013 & 0,919 & 0,312 & & & & \\
\hline 9 & 2014 & 0,0486 & 0,0420 & & & & \\
\hline 10 & 2015 & 0,0281 & & & & & \\
\hline 11 & 2016 & 0,0638 & & & & & \\
\hline
\end{tabular}

Berdasarkan fenomena Kota Mataram itu sendiri yakni selalu mengalami trend positif dan seiring berjalannya waktu pertumbuhannya mengalami perlambatan, sehingga nilai parameter $\mathrm{r}$ yang digunakan adalah harga $\mathrm{r}$ dengan space 4 tahun yakni 0,122 ; 0,$098 ; 0,085 ; 0,055$.

Tabel 5. Laju Pertumbuhan dan MAPE Masing-Masing Selang Pengambilan Sampel Model Logistik

\begin{tabular}{cccc}
\hline \multirow{2}{*}{ Aproksimasi } & $\begin{array}{c}\text { Populasi awal } \\
\left(\boldsymbol{P}_{\mathbf{0}}\right)\end{array}$ & $\begin{array}{c}\text { Laju pertumbuhan } \\
(\mathbf{r})\end{array}$ & $\begin{array}{c}\text { MAPE } \\
(\mathbf{\%})\end{array}$ \\
\hline & 2006 & & 76,8 \\
2007 & 0,122 & 60,1 \\
$\mathbf{I}$ & 2008 & & 44,8 \\
& 2009 & & 39,1 \\
& 2010 & & 54,7 \\
\hline & 2006 & & 31,6 \\
& 2007 & 0,098 & 15,3 \\
$\mathbf{I I}$ & 2008 & & 4,5 \\
& 2009 & & 4,1 \\
& 2010 & & 24,6 \\
\hline
\end{tabular}




\begin{tabular}{cccc}
\hline \multirow{2}{*}{ Aproksimasi } & $\begin{array}{c}\text { Populasi awal } \\
\left(\boldsymbol{P}_{\mathbf{0}}\right)\end{array}$ & $\begin{array}{c}\text { Laju pertumbuhan } \\
(\mathbf{r})\end{array}$ & $\begin{array}{c}\text { MAPE } \\
(\mathbf{\%})\end{array}$ \\
\hline \multirow{4}{*}{ III } & 2006 & & 2,4 \\
& 2007 & & 13,0 \\
& 2008 & 0,0850 & 22,8 \\
2009 & & 20,6 \\
& 2010 & & 6,1 \\
\hline \multirow{3}{*}{ IV } & 2006 & & 72,2 \\
& 2007 & 0,055 & 81,2 \\
& 2008 & & 82,4 \\
& 2009 & & 74,3 \\
& 2010 & & 37,3 \\
\hline
\end{tabular}

Apabila diperhatikan, peneliti mendapatkan beberapa model aproksimasi dengan laju pertumbuhan dan variasi terhadap populasi awal $P_{0}$ dengan masing-masing kriterianya atau keakuratannya. Peneliti menyimpulkan bahwa model logistik yang akurat untuk digunakan dalam proyeksi penduduk adalah model aproksimasi III dengan laju pertumbuhan sebesar 0,0844 dengan populasi awal $\left(P_{0}\right)$ adalah data tahun 2006 . Hal ini dikarenakan model ini memiliki nilai error terkecil dengan MAPE sebesar 2,1\%. Untuk melanjutkan proyeksi jumlah penduduk Kota Mataram pada tahun 2024, diperoleh harga $t=19$. Jadi estimasi jumlah penduduk Kota Mataram pada tahun 2024 menggunakan model ini adalah sekitar 520.062 jiwa.

\subsection{Perhitungan model eksponensial dan logistik}

Setelah dilakukannya perhitungan dengan masing-masing model, diperoleh bahwa estimasi jumlah penduduk Kota Mataram yang dilakukan dengan mengunakan model eksponensial ini memiliki tingkat kepercayaan yang lebih baik daripada model logistik. Tentunya hasil dari penelitian ini bukannya tidak relevan, tetapi untuk efektif dan relevannya suatu model estimasi bergantung pada kondisi dan kriteria pertumbuhan penduduk itu sendiri yakni dimana di Kota Mataram masih memiliki ruang untuk memungkinkan terjadinya suatu pertumbuhan yang eksponen (pertambahan penduduk).

Sebagai suatu referensi bahwa jika suatu wilayah masih memberi ruang yang cukup untuk menampung kehidupan populasi di dalamnya, maka dapat mengestimasi dengan menggunakan model pertumbuhan eksponensial dengan pengestimasian hanya untuk beberapa waktu ke depan saja, hal ini dikarenakan oleh rentang waktu sampel penelitian hanya beberapa tahun saja dan model ini pula tidak dapat memperkirakan kapasitas tampung yang dapat dimuat oleh suatu wilayah, sehingga model ini memberikan suatu peluang untuk terjadinya ledakan populasi jika estimasinya dalam rentang waktu yang panjang.

Sedangkan jika yang terjadi adalah hal sebaliknya, maka dapat digunakan model logistik. Dengan model logistik dapat diketahui kapasitas tampung wilayah dan angka penekanan terhadap laju pertumbuhan untuk memungkinkan pertumbuhan yang dikatakan wajar dan efektif, dengan kata lain kesenjangan penduduk dapat 
terminimalisir sehingga mendukung penuh kehidupan populasi di dalamnya dalam berdaya saing dan menciptakan sumberdaya manusia yang unggul.

\section{PENUTUP}

Hasil perhitungan dari kedua model tersebut (eksponensial dan logistik) menunjukkan bahwa dinamika pertumbuhan penduduk Kota Mataram pada masa yang akan datang mengalami penambahan jumlah tetapi akan adanya perlambatan pertumbuhan sebesar 0,5\% per 2 tahun sekali. Untuk estimasi yang dilakukan terhadap jumlah penduduk Kota Mataram pada tahun 2024 adalah disarankan menggunakan model eksponensial karena memiliki tingkat kepercayaan yang tinggi dan Kota Mataram masih memiliki ruang yang cukup untuk pertumbuhan ini. Adapun hasil estimasi jumlah penduduk di Kota Mataram pada tahun 2024 adalah sebesar 526.085 jiwa.

\section{REFERENSI}

Badan Pusat Statistik (BPS) NTB. (2019). Kependudukan dan Ketenagakerjaan. In Katalog Kota Mataram Dalam Angka Mataram Municipality In Figures 2019. Mataram: Badan Pusat Statistik Nusa Tenggara Barat.

Nurkholipah, N. S., Anggriani, N., \& Supriatna, A. K. (2017). Perbandingan Proyeksi Penduduk Jawa Barat Menggunakan Malthus dan Verhust dengan Variasi Internal Pengambilan Sampel. Jurnal DIALEKTIKA, 1(1), 195-202. Retrieved from https://jurnal.untan.ac.id/index.php/jbmstr/article/view/5189

Purcell, E., \& Varberg, D. (1993). Persamaan Diferensial. In E. J. Purcell, \& D. Varberg, Kalkulus dan Geometri Analitis Jilid 2 Terjemahan oleh I Nyoman Susila dkk (5th ed.). Jakarta: Erlangga.

Putri, W. (2015). Perbandingan Model Malthus Dan Model Verhulst Untuk Estimasi Jumlah Penduduk Indonesia Tahun 2000 - 2014. Jurnal Matematika UNAND, 4(1), 1. https://doi.org/10.25077/jmu.4.1.1-11.2015

Stewart, J. (2003). Persamaan Diferensial. In J. Stewart, Kalkulus Terjemahan oleh I Nyoman Susila dkk. Partial Differential Equations and Complex Analysis. Jakarta: Erlangga.

Sugiyono. (2010). Metode Penelitian Kuantitatif, Kualitas, dan R\&D (10th ed.). Bandung: Alfabeta.

Toaha, S. (2008). Model Dengan Tundaan Waktu, 4(2), 13-22.

Zulkarnaern, D. (2014). Proyeksi Populasi Penduduk Kota Bandung Menggunakan Model Pertumbuhan Populasi Verhulst dengan Memvariasikan Interval Pengambilan Sampel. In Prosiding SI MaNIs (Seminar Nasional Integrasi Matematika dan Nilai-Nilai Islami) (Vol. VIII, pp. 159-181). 